\title{
Anti-candidal effect of endophytic fungi isolated from Calotropis gigantea
}

\author{
Archana Nath \& Santaram Joshi* \\ Microbiology Laboratory, Department of Biotechnology and Bioinformatics, North-Eastern Hill University, \\ Shillong-793022, India; srjoshi2006@yahoo.co.in, archananath3@gmail.com \\ * Correspondence
}

Received 16-IX-2016. Corrected 11-V-2017. Accepted 13-VI-2017.

\begin{abstract}
Candida albicans is a most common cause of fungal infections in animals and birds. Understanding the increasing resistance of $C$. albicans to various antifungal therapeutic agents is important to discover new anti-candidal alternatives. The present study investigated the anti-candidal potential of five endophytic fungi extracts, isolated from the tropical ethnoveterinary plant, Calotropis gigantea. We firstly evaluated the in vitro antifungal activities of endophytic fungi extracts by the well diffusion method. Secondly, the cells of C. albicans were treated with the potent extract to observe significant ultrastructural changes. To further investigate the in vivo antifungal activity of the extract, some laboratory experiments with mice were undertaken, and posteriourly, the different organs were studied under the electron microscope for any deformities. Phomopsis asparagi showed the best anti-candidal activity with a minimum inhibitory concentration (MIC) of $46.9 \mu \mathrm{g} / \mathrm{mL}$. The fungal test pathogen (C. albicans) exhibited various cell deformities when treated with the extract of P. asparagi. Histopathological studies of the vital organs of mice treated with the potent fungal extract did not show any significant pathological conditions when viewed under scanning electron microscope. Thus, $P$. asparagi can be a potential candidate for anti-candidal agents against $C$. albicans. Future studies will focus on the isolation of the bioactive components of the extract. Rev. Biol. Trop. 65 (4): 1437-1447. Epub 2017 December 01.
\end{abstract}

Key words: endophytic fungi, anti-candidal, Candida albicans, scanning electron microscope, ultrastructure.

Candida albicans is recognized to cause many important diseases in animals and birds, and represents an important veterinary pathogen. C. albicans mostly affects birds causing thrush affecting the oral mucosa, oesophagus and crop. Cattle, calves, sheep and foals are also susceptible to systemic candidiasis which occurs as a consequence of prolonged treatment with antibiotics and corticosteroids (Kuwamura, Ide, Yamate, Shiraishi, \& Kotani, 2006). C. albicans infections faces a number of problems including limited number of effective antifungal agents, toxicity of the available antifungal agents, resistance of Candida to commonly used antifungal, relapse of Candida infections and non-cost effective antifungal agents (Sasidharan, Zuraini, Latha, \& Suryani,
2008). Therefore, there is an urgent need to design new drugs and to explore alternative sources of novel drugs.

Northeast (NE) India is considered one of the most important biodiversity hotspots of the globe with a wide range of physiographic and ecoclimatic conditions (Myers, Mittermeier, Mittermeier, Fonseca, \& Kent, 2000). Northeast India in the Eastern Himalayan range is located between $20^{\circ} 35^{\prime} 37.2624^{\prime \prime} \mathrm{N}-7^{\circ} 57^{\prime} 46.368^{\prime \prime} \mathrm{E}$, and sprawling over $262379 \mathrm{~km}^{2}$ (Lyngwi, Koijam, Sharma, \& Joshi, 2013). In tropical and subtropical countries, with hot and humid climates like India, with ideal conditions for fungal infections, turn them into a common problem among human and animal populations (Naglot et al., 2015). These areas, with hot, 
humid and muggy weather, have favoured the growth of different fungal infections, and have worsened the symptoms of candida infections (Pannu, McCarthy, Martin, \& Sutcliffe, 2009).

In Northeast India, the ethnoveterinary plant Calotropis gigantea is widely used by the local livestock farmers to increase appetite in animals. Furthermore, there are reports on the biological activities of this plant, to treat common diseases such as fevers, rheumatism, indigestion, cough, cold, eczema, asthma, elephantiasis, nausea, vomiting, and diarrhea (Srivastava, Singh, \& Rawat, 2015). However, there are no reports on the biological activities of the endophytic fungi associated with these plants. Endophytes are harmless residents of the internal living tissues of plants (Bacon \& White, 2000). These are known to produce some bioactive secondary metabolites which can protect their hosts from infectious agents and adverse conditions, and produce pharmacologically active compounds (Strobel, Daisy, Castillo, \& Harper, 2004; Verma, Kharmar, \& Strobel, 2009). In previous works, there have been some reports on the antimicrobial (Tanaka, Fukushima, Tsujiro, \& Fujimori, 1997; Gong \& Guo, 2009; Du, Li, Li, Shang, \& Wang, 2012), antioxidant (Huang, Chen, Chang, Sheu, \& Lin, 2007; Dhankhar, Kumar, Dhankhar, \& Yadav, 2012; Nath, Raghunatha, \& Joshi, 2012), anti-inflammatory (Deshmukh et al., 2009; Pretsch et al., 2014) activity of the endophytic fungi. Besides, some in vivo studies on the anti-cancer, anti-diabetic and other bioactivity (Konrath et al., 2012; Govindappa et al., 2015; Tan et al., 2015) have been evidenced, but in vivo antimicrobial studies on endophytic fungi are very scarce (Peláez et al., 2000; Nath \& Joshi, 2016).In the present study, we aimed to identify $C$. gigantea fungal endophytes and to characterize their anti-candidal activity in an in vivo model.

\section{MATERIALS AND METHODS}

Collection of plant samples: Based on adequate information obtained from the local farmers of the tribal belts of Northeast India, the stem and leaves of the ethnoveterinary plant, Calotropis gigantea L. were collected in the month of April, 2013 (Vegetative form). The samples were then brought to the laboratory and were kept in $4{ }^{\circ} \mathrm{C}$ for further processing.

Isolation of endophytic fungi: Plants were washed properly in running tap water and different parts of the plants (stem and leaves) were excised into segments of $0.5-1 \mathrm{~mm}$ in length. The segments were kept in $70 \%$ ethanol (Lab Chemicals Ltd., India) for $1 \mathrm{~min}$ followed by $4 \%$ sodium hypochlorite solution for $3 \mathrm{~min}$ and again kept in $70 \%$ ethanol for $1 \mathrm{~min}$. The segments were rinsed thoroughly in sterile distilled water and then kept in laminar airflow for drying. Properly dried segments were inoculated into Potato Dextrose agar (PDA) supplemented with $100 \mu \mathrm{g} / \mathrm{mL}$ of streptomycin and incubated at $25{ }^{\circ} \mathrm{C}$ until fungal growth appeared from the segments (Petrini, 1986). Hyphal tips from the fungal growth were then subcultured to fresh PDA plates and preserved in sterile distilled water at room temperature.

Molecular characterization of endophytic fungi: Genomic DNA was isolated from the respective isolates using genomic DNA extraction kit (HiMedia, India). PCR amplification and sequencing of ITS rRNA gene was carried out in a $50 \mu \mathrm{L}$ reaction mixture using primers ITS1 and ITS4 with the following conditions, denatured at $94{ }^{\circ} \mathrm{C}$ for $5 \mathrm{~min}$ followed by 30 cycles at $94{ }^{\circ} \mathrm{C}$ for $1 \mathrm{~min}$, annealing at $52{ }^{\circ} \mathrm{C}$ for $30 \mathrm{sec}$, extension at $72{ }^{\circ} \mathrm{C}$ for $1 \mathrm{~min}$, final step was carried out at $72{ }^{\circ} \mathrm{C}$ for $10 \mathrm{~min}$ (Nath \& Joshi, 2016) using PCR Gene Amp 9700 (Applied Biosystems, USA). The amplified ITS rRNA gene was then purified using QIAquick Gel Extraction Spin Kit (QIAGEN, Germany). Sequencing of ITS rRNA gene were performed with the Big Dye Terminator v3.1 Cycle Sequencing Kit (Applied Biosystems, USA) using the same forward and reverse primers. The nucleotide sequences were then analyzed with the sequences obtained from NCBI database using BLAST and aligned by using the Clustal W program. Phylogenetic 
tree was constructed using MEGA 4.1 software (Tamura et al., 2011). The sequences were deposited to the NCBI database and accession numbers were obtained.

Preparation of plant extract: The stem and leaves of $C$. gigantea were thoroughly washed in running water and then were finally rinsed in distilled water. The washed plants samples were then air dried in hot air oven at $50{ }^{\circ} \mathrm{C}$ for $72 \mathrm{~h}$ with forced air, after which the dried plants were grounded into smooth powder by using a clean pestle and mortar. Then, $100 \mathrm{~g}$ of the powdered plant sample were dissolved in ethanol $(300 \mathrm{~mL})$ for 4 days at room temperature with intermittent stirring. After four days, the mixture was filtered through Whatman No. 1 paper and was concentrated under vacuum using a rotary evaporator. The dried crude plant extract was then dissolved in dimethylsulfoxide (DMSO) to make a final concentration of $5 \mathrm{mg} / \mathrm{mL}$, and then were sterilized by filtration using a $0.22 \mu \mathrm{m}$ membrane for antimicrobial assay (Vijayarathna et al., 2012). The resultant extract was kept at $4{ }^{\circ} \mathrm{C}$ for further analysis.

Extraction of fungal crude extract: Fungal hyphae were cut into small pieces and were inoculated in a conical flask containing 100 $\mathrm{mL}$ of sterile potato dextrose broth (PDB). The flask was then incubated at $25{ }^{\circ} \mathrm{C}$ for $10-15$ days. After obtaining proper growth, the broth was filtered through muslin cloth to separate the mycelia from the broth. The filtrate was then mixed with thrice the volume of $70 \%$ ethyl alcohol and filtered through Whatman filter paper No.1. The solvent phase was evaporated under reduced pressure using rotary vaccum evaporator at $50{ }^{\circ} \mathrm{C}$ (Nath \& Joshi, 2013). The residues were re-dissolved in $50 \%$ dimethyl sulphoxide (DMSO) to make a final concentration of $5 \mathrm{mg} / \mathrm{mL}$ for subsequent analysis.

In vitro antimicrobial activity by well diffusion method: The antimicrobial activity of the ethanolic extract of endophytic fungi was tested against the Candida albicans (MTCC 183). All the tests were performed in triplicates.
Test fungus was subcultured on Potato dextrose broth (PDB) for $48 \mathrm{~h}$. The antifungal test was carried out on Mueller Hinton Agar (MHA) plates. Mueller Hinton agar plates were prepared and a well of $7 \mathrm{~mm}$ was made with sterile cork borer. One milliliter of broth containing the test micro-organisms was swapped on the agar plates. A volume of $50 \mu \mathrm{L}$ of extracts was put in the wells and the plates were incubated at $37{ }^{\circ} \mathrm{C}$ for $24-48 \mathrm{~h}$. The plates were then observed for inhibition zone (Nath, Chattopadhyay, \& Joshi, 2015).

Determination of Minimum inhibitory concentration (MIC): MIC of the plant and fungal extracts along with the standard drug Fluconazole was determined by NCCLS Broth Microdilution (BM) method on sterile microtiter plate with 96 flat bottomed (Nascente et al., 2009) with slight modifications. The $C$. albicans isolate was suspended in saline solution with the turbidity adjusted to level 1 of the McFarland scale. A total of $100 \mu \mathrm{L}$ of Potato dextrose Broth were dispensed in each well. The stock solution of the extracts was diluted to a concentration of $1.5 \mathrm{mg} / \mathrm{mL}$ and $50 \mu \mathrm{L}$ were transferred into the first well, followed by serial dilution of the stock solution of extract to get the concentrations in the range of $1.5-1500 \mu \mathrm{g} / \mathrm{mL}$. Then $100 \mu \mathrm{L}$ of saline solution containing fungal suspension was added to all the wells. The plates were then sealed properly to avoid dehydration of fungus and were incubated at $37^{\circ} \mathrm{C}$ for $72 \mathrm{~h}$. The readings were made visually, comparing the growth of the fungus in all the test wells with the well that had the positive control. MIC was taken as the lowest concentration that produced a significant inhibition (around $50 \%$ ) of the growth of the fungi with the positive control.

\section{Ultrastructural analysis of pathogens by} scanning electron microscopy (SEM): After treatment with the potent endophytic fungi, the test pathogens were analysed under scanning electron microscope (JSM-6360, Jeol) for their ultrastructural deformities. Test organisms were treated with $4 \mathrm{x}$ concentration of the MIC 
of the fungal extracts and incubated overnight at $37^{\circ} \mathrm{C}$. The cells were pelleted after centrifugation at $8000 \mathrm{rpm}$ for $15 \mathrm{~min}$. The pellets were then washed with PBS pH 7.3 several times to remove the debris and fixed in $2.5 \%$ glutaraldehyde in $0.1 \mathrm{M}$ cacodylate buffer $(\mathrm{pH}$ 7.2) for $4 \mathrm{hr}$. Glutaraldehyde was drained carefully and the pellets were washed again in PBS for several times to remove any traces of glutaraldehyde. The pellets were then smeared on small glass slide and brought to room temperature for drying. Finally, samples were sputter coated with a thin layer of gold-palladium and scanned under SEM.

Experimental animals: Male Swiss albino mice weighing between $25-30 \mathrm{~g}$ and aged between 5-6 weeks were procured from Pasteur's Institute, Shillong, Meghalaya. Mice in cages were placed in a room (temperature 25 $\pm 2{ }^{\circ} \mathrm{C}$ ) with controlled cycles of $12 \mathrm{~h}$ of light and $12 \mathrm{~h}$ of darkness. Water and food (Amrut, India) were provided to animals ad libitum. The experimental protocols were approved by the Institutional Animal Ethics Committee (IAEC). The mice were acclimatized for one week before the experiments were carried out.

Acute toxicity studies: Acute oral toxicity test was performed as per OECD-423 guidelines (Ecobichon, 1992). Before the conduct of the experiment, the animals were starved for $24 \mathrm{~h}$ with free access to ad libitum water. Different animal groups were administered orally with the extracts at a dose level of $10 \mathrm{mg} / \mathrm{kg}$ body weight and were observed for 2 weeks. If among a group of six mice there was mortality seen in 2-3 mice, the dose was then considered as a toxic dose, and if only one animal died, then the same dose was repeated for the confirmation of toxic dose. If there was no mortality in the different animal groups (six in each group), then those animals were administered with extract doses of 100, 250, 500, $1000 \mathrm{mg} /$ $\mathrm{kg}$ body weight. Subsequently, the animals were observed for any toxicity/mortality for the next 14 days.
Study of antifungal activity in mice: The animals were divided into five groups consisting of five animals in each group: Control (Gp1) which received only sterile distilled water. C. albicans was grown for $72 \mathrm{hrs}$ in PDB, centrifuged and washed in phosphate buffered saline and finally diluted in PBS to achieve $\sim 1 \times 10^{5} \mathrm{CFU} / \mathrm{mL}$. A volume of 0.1 $\mathrm{mL}$ of the fungal suspension was administered to the different groups (Gp 2-5) of animals through the intravenous route (Vijayarathna et al., 2012). After $1 \mathrm{~h}$ of post infection, the animal groups $(\mathrm{Gp} \mathrm{3,4)}$ were administered orally with the fungal extract at doses of 100 and 250 $\mathrm{mg} / \mathrm{kg}$ body $\mathrm{wt}$, respectively for eight successive days. Fluconazole at a concentration of $10 \mathrm{mg} / \mathrm{kg}$ body weight was administered orally to the last group of animals (Gp 5). Different animal groups were checked for any change in body weight and body temperature every alternate day.

\section{Assessment of fungal infection in vital} organs: To assess the efficacy of fungal extract treatment on the establishment of infection in animals, two animals from each group were sacrificed on day 4 after infection and the rest of the animals after the end of the experiment i.e. on day 8 . Liver and spleen samples from the sacrificed animals were collected aseptically, homogenized properly in sterile PBS and were swapped on Potato dextrose agar for the reisolation of the organism to observe the number of viable fungi (Owais, Sharad, Shehbaz, \& Saleemuddin, 2005).

Scanning electron microscope (SEM) observation of tissues: The liver and spleen tissues of mice were cut into small segments and were fixed in $2.5 \%$ glutaraldehyde in 0.1 $\mathrm{M}$ cacodylate buffer ( $\mathrm{pH}$ 7.2) for $12 \mathrm{~h}$. Glutaraldehyde was drained out carefully and washed thrice for $1 \mathrm{~h}$ in $0.1 \mathrm{M}$ cacodylate buffer. The samples were dehydrated with acetone series $(50,70,80,90,95$ and $100 \%)$ and drying was done with TMS (Trimethyl silane). Tissues were immersed twice in TMS for $10 \mathrm{~min}$ at $4{ }^{\circ} \mathrm{C}$ and were brought to room temperature 
for drying. Finally, samples were sputter coated with a thin layer of gold-palladium and scanned under SEM.

The results of antifungal activity were expressed as mean $\pm \mathrm{SE}$ values and data were tested by one-way analysis of variance. Differences were considered significant at $p<0.05$.

\section{RESULTS}

Isolation of endophytic fungi: In this study, a total of five endophytic fungi, three from the stems and two from the roots of the ethnoveterinary plant ( $C$. gigantea), and were isolated based on morphological characteristics. The endophytic fungi were identified as Phomopsis asparagi, two strains of Colletotrichum gloeosporioides, Calonectria eucalypti and Xylaria sp. (Fig. 1). All the endophytic fungi were isolated from leaves, except $P$. asparagi which was isolated from the stem. The fungal isolates were further characterized based on the analysis of the phylogenetic relationship of the isolates using ITS region gene sequences. The ITS gene sequences of all the fungal isolates were submitted to NCBI GenBank and accession numbers were obtained (KF928280, KF928284, KM282291, KF928290 and KF928285).

Antifungal activity: Among the five endophytic fungi, only $P$. asparagi and $C$. gloeosporioides, showed antifungal activity against $C$. albicans. The ethanolic extract of $P$. asparagi showed considerable anti-candidal activity as it showed a highest inhibition zone. The plant extract of $C$. gigantea also showed antifungal activity with a narrow inhibition zone (Table 1). Considering their inhibition zone, results showed antifungal activity from the different endophytic fungi, and were significantly $(p<0.05)$ different from each other.

\section{Minimum inhibitory concentration} (MIC): MICs of all tested fungal extracts ranged from 46.9-375 $\mu \mathrm{g} / \mathrm{mL}$ (Table 1).

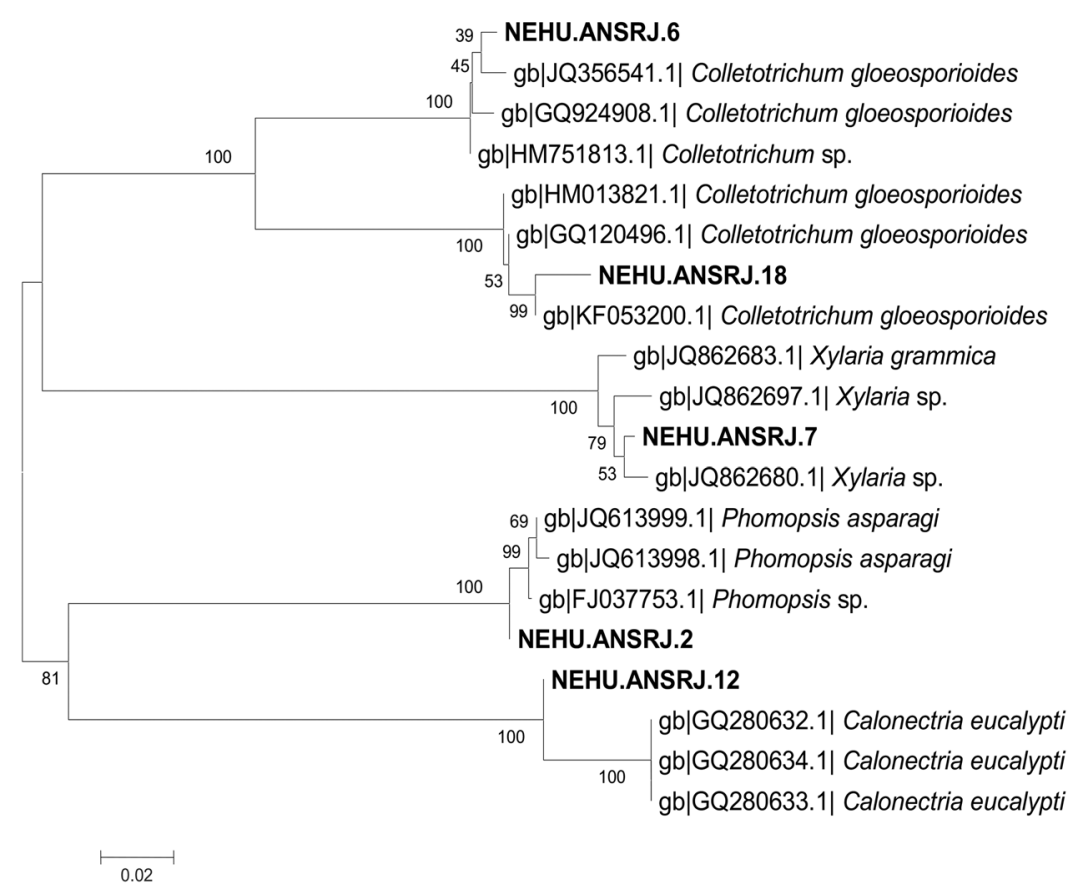

Fig. 1. Phylogenetic relationships generated for the five endophytic fungi isolated from Calotropis gigantea L. and the ITS sequences of closely related fungal strains retrieved (14 March, 2016) from NCBI GenBank. 
TABLE 1

Inhibition zone and minimum inhibitory concentration observed for the ethanolic extracts of endophytic fungal and plant when compared to Fluconazole

\begin{tabular}{llcc} 
& \multicolumn{1}{c}{ Ethanolic Extract $(5 \mathrm{mg} / \mathrm{mL})$} & Inhibition Zone $(\mathrm{mm})$ & $\mathrm{MIC}(\mu \mathrm{g} / \mathrm{mL})$ \\
Endophytic fungi & Phomopsis asparagi (NEHU. ANSRJ.2) & $23 \pm 0.67$ & 46.9 \\
& Colletotrichum gloeosporioides (NEHU. ANSRJ.6) & - & - \\
& Colletotrichum gloeosporioides (NEHU. ANSRJ.18) & $16 \pm 0.58$ & 93.75 \\
& Calonectria eucalypti (NEHU. ANSRJ.12) & - & - \\
& Xylaria sp. (NEHU. ANSRJ.7) & - & 375 \\
Plant & Calotropis gigantea & $12 \pm 0.58$ & 11.8 \\
Antibiotic & Fluconazole & $28 \pm 0.67$ & - \\
Negative Control & Sterile Water & - & - \\
\hline
\end{tabular}

The ethanolic extract of $P$. asparagi showed a significant anti-candidal activity with a MIC of $46.9 \mu \mathrm{g} / \mathrm{mL}$. Besides, the Fluconazole positive control also showed significant anti-candidal activity (MIC $11.8 \mu \mathrm{g} / \mathrm{mL}$ ) when compared to plant and fungal extracts.

SEM analysis of pathogens ultrastructure: The fungal test pathogen also revealed various cell deformities when treated with the extract of Phomopsis asparagi. Normal cells of $C$. albicans were spherical with smooth walls, while the treated fungal cells showed presence of deformities such as wrinkled and disintegrated structures. Further several small invaginations and convolutions appeared on C. albicans cell surfaces after the treatment (Fig. 2). Approximately, $70 \%$ of the treated $C$. albicans cells were found to show structural deformities.
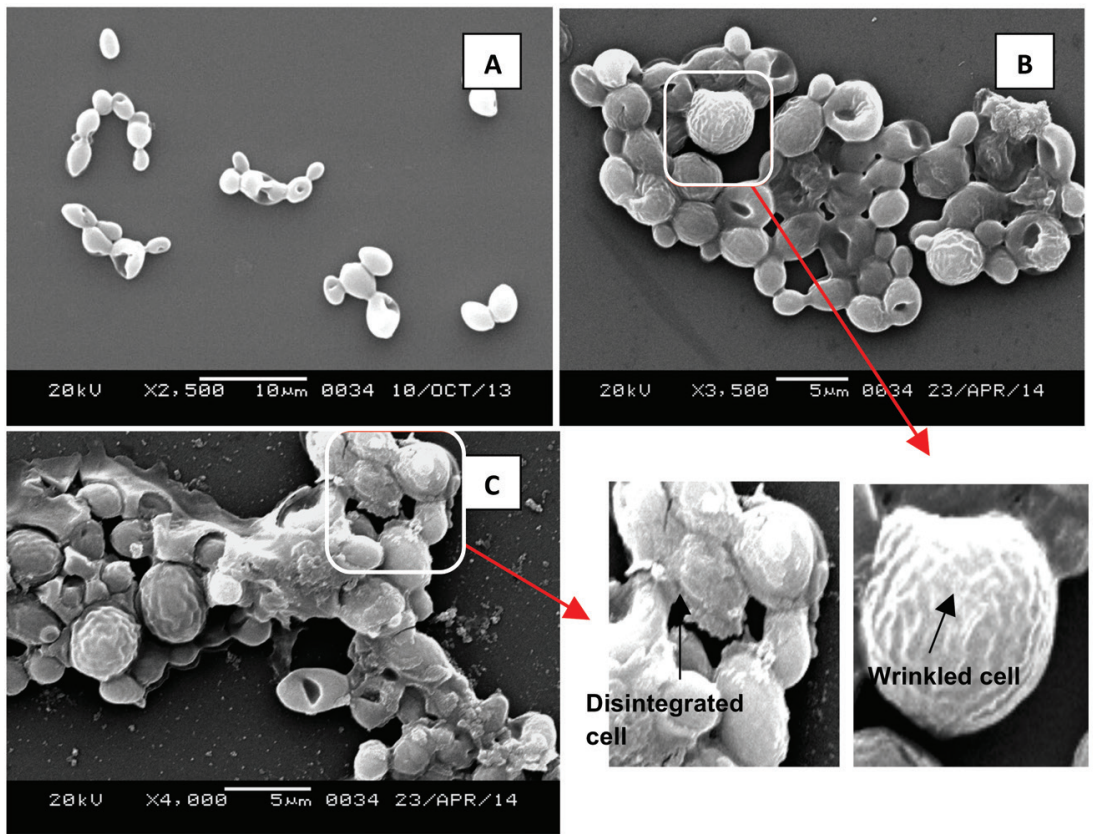

Fig. 2. (A) SEM micrographs of normal fungal cell of C. albicans, (B) Presence of wrinkled cells with a few normal cells of C. albicans, (C) Disintegrated cells of C. albicans. 
TABLE 2

Candida albicans count (CFU/g of tissue) in vital organs of mice model treated with ethanolic extract of Phomopsis asparagi and antibiotics

\begin{tabular}{lcc} 
& \multicolumn{1}{c}{ Animal Groups } & Fungal load in liver (CFU/g of tissue) post infection \\
& 4 days & N days \\
Gp 1 (Control) & ND & $2.1 \times 10^{7}$ \\
Gp 2 (Infected) & $1.11 \times 10^{5}$ & $1.98 \times 10^{5}$ \\
Gp 3 (Infected+ crude extract at $100 \mathrm{mg} / \mathrm{kg}$ body wt. of animal) & $1.22 \times 10^{5}$ & $1.12 \times 10^{4}$ \\
Gp 4 (Infected+ crude extract at $250 \mathrm{mg} / \mathrm{kg}$ body wt. of animal) & $1.38 \times 10^{4}$ & $1.13 \times 10^{3}$ \\
Gp 5 (Infected+ Fluconazole at $10 \mathrm{mg} / \mathrm{kg}$ body wt. of animal) & $1.65 \times 10^{3}$ & \\
\hline
\end{tabular}

ND- Not Detected.

Acute toxicity test: The fungal isolate (P. asparagi), which showed significant anticandidal activity in terms of the highest zone of inhibition and MIC, were then evaluated in vivo by testing the extract in the mice model. No mortality was seen in the animals, however, animal groups administered with the extract doses of 500 and $1000 \mathrm{mg} / \mathrm{kg}$ body wt showed tachycardia. Hence, the doses of 100 and $250 \mathrm{mg} / \mathrm{kg}$ body weight were determined as safe for the experiment.

Antifungal activity in animals: The animals of Gp 4 and Gp 5 treated with $250 \mathrm{mg} / \mathrm{kg}$ body wt. extract and $10 \mathrm{mg} / \mathrm{kg}$ body wt. fluconazole showed a high survival rate of 80 and 100 $\%$, respectively. Gp 2 showed $80 \%$ mortality rate within seven days of infection. Gp 3 with an extract dose of $100 \mathrm{mg} / \mathrm{kg}$ body wt., did not show therapeutic effect on the animals, and 40 $\%$ mortality was observed. The extract with a concentration of $250 \mathrm{mg} / \mathrm{kg}$ body wt. showed a good effect to lower mortality and $80 \%$ survival rate, and its effect was near comparable to the commercial antibiotic fluconazole having $100 \%$ survival rate. No significant changes were observed on the different group of animal's body temperature, but a gradual loss of body weight was observed in Gp 2 and Gp 3. A significant reduction in colony forming unit (CFU) was observed in the liver of members of $\mathrm{Gp} 4$ and $\mathrm{Gp} \mathrm{5,} \mathrm{which} \mathrm{received} \mathrm{the} \mathrm{extract} \mathrm{at} \mathrm{a}$ dose of $250 \mathrm{mg} / \mathrm{kg}$ body wt. and fluconazole at a dose of $10 \mathrm{mg} / \mathrm{kg}$ body wt., when compared to control group (Table 2).

SEM analysis of vital organs: Tissues samples (liver and spleen) of the different groups of infected animals with Candida albicans, and those treated with the potent extract and the reference drug Fluconazole, were analyzed under SEM for any pathological changes. SEM analysis of the C. albicans cells treated with the potent extract ( $P$. asparagi) showed ultrastructural deformities like wrinkled and disintegrated structures. Liver samples showed marked histopathological changes (Fig. 3) in the the affected animals, compared to the normal tissues of the healthy animals; but no changes could be found in spleen tissues.

\section{DISCUSSION}

The approaches used in this study attained the endophytes identification beyond the generic level. These were identified as Phomopsis asparagi, Colletotrichum gloeosporioides, Calonectria eucalypti and Xylaria sp. The phylogenetic analysis of their ITS rDNA sequences, resulted in a useful region for the molecular characterization and proper identification of fungal isolates (Bridge \& Arora, 1998).

Among the five isolated endophytic fungi, only $P$. asparagi and $C$. gloeosporioides showed antifungal activity against $C$. albicans. Our data indicated that the fungal extracts 

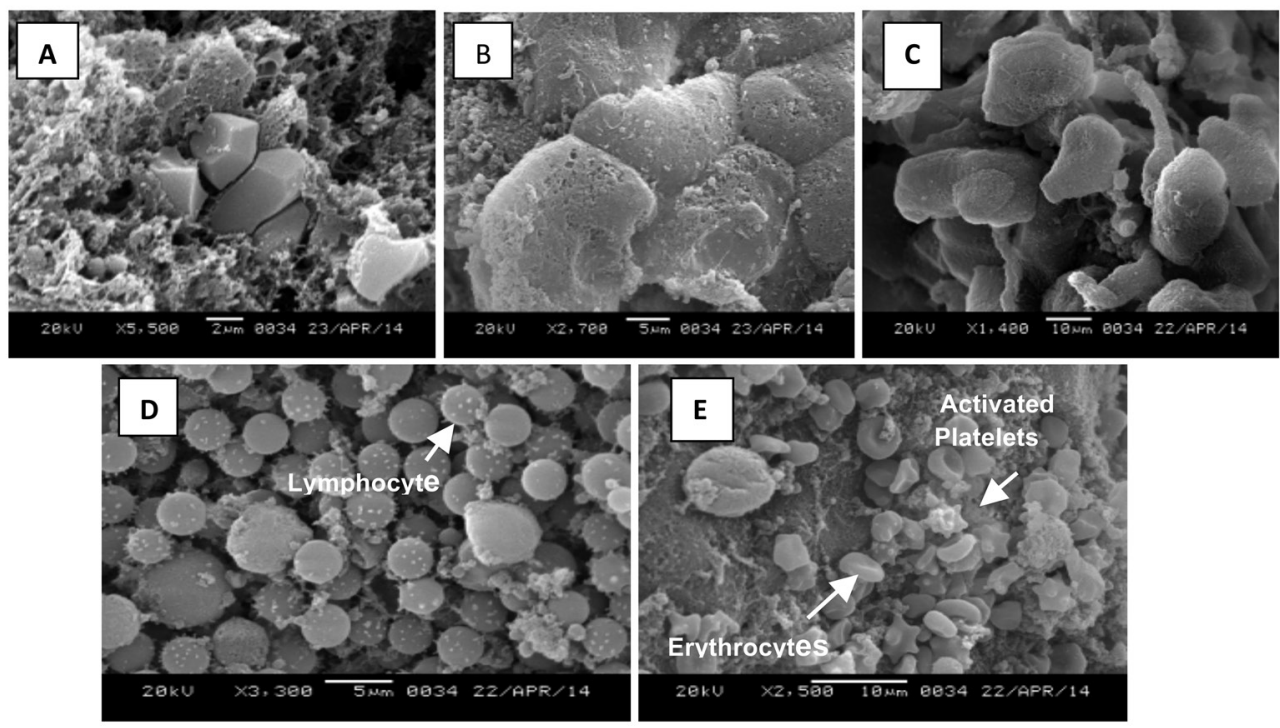

Fig. 3. (A) Scanning electron micrographs of liver cells of normal control mice showing smooth hepatocytes. (B) Mice infected with C. albicans showing rough and disintegrated cell surface of hepatocytes. (C) Treated group of mice (100 mg/kg body wt.) showing presence of both normal and disintegrated hepatocytes. (D) (E) Treated group of mice (250 mg/kg body wt.) showing presence of lymphocytes and activated platelets along with erythrocytes.

showed better anti-candidal activity than the plant extract. The potent anti-candidal activity was revealed by $P$. asparagi in terms of the highest zone of inhibition $(23 \mathrm{~mm})$, which is comparable to that of the standard Fluconazole (26 mm) with $P$. asparagi, showing the lowest MIC of $46.9 \mu \mathrm{g} / \mathrm{mL}$ against $C$. albicans. Isolation of $P$. asparagi from the medicinal plant has been reported earlier (Faria et al., 2016) but no report on anti-candidal activity of these endophytic fungi is available.

SEM study was used to view any surface alterations or general morphological changes of C. albicans cells after exposure to P. asparagi extract, which corroborated the in vitro antimicrobial results observed. Our SEM analysis of the $C$. albicans cells treated with the potent extract of $P$. asparagi, showed the ability of the extract to cause damage to the fungal pathogen. These results are in agreement with Vijayarathna et al. (2012) report, which also showed the destruction of cell membrane of Candida albicans cells.

In vivo activity of medicinal plants has been scarcely reported (Vijayarathna et al.,
2012) and this represents one of the first reports available on the anti-candidal properties of endophytic fungi. In the present study, the most potent endophyte, $P$. asparagi was subjected to in vivo assays to assess its efficacy in an animal model, in cognizance to the artificial systemic infection of C. albicans in mice (Vijayarathna et al., 2012). The use of an in vivo model in mice was suggested by previous results of in vivo oral toxicity tests, in which the dose rate of $100 \mathrm{mg} / \mathrm{kg}$ body weight and $250 \mathrm{mg} / \mathrm{kg}$ body weight were considered safe for the experiment, since it did not show any mortality or abnormal physiological changes. In the animal model of this study, the fungal extract of $P$. asparagi at a dose of $250 \mathrm{mg} / \mathrm{kg}$ body weight, showed significant antifungal activity, in terms of low mortality, low fungal load in liver, and minor histopathological conditions in liver of the affected animal. Besides, SEM analysis of liver tissues, showed marked pathological changes in the affected and treated group of animals (wrinkled and disintegrated structures) in comparison to that of the normal tissues of healthy animals. The liver of the treated animals also 
showed the presence of various immune cells like lymphocytes and platelets which play an important role in combating infections. The liver of the affected group showed the presence of disintegrated hepatocytes, whereas the treated group showed the presence of both disintegrated and normal hepatocytes which is in agreement with the histopathological findings of Khan et al. (2003) who reported the preservation of healthy architecture of the liver cells, which was attributed to liver regeneration. However, no such changes were observed in spleen tissues of the affected and treated animals. The results suggested that the $P$. asparagi extract possess both the fungicidal activity and the ability to potentiate the immune system as it can destroy Candida cells as well as activate various immune cells like lymphocytes and platelets.

During the last three decades, C. albicans has been the most prevalent pathogen in systemic fungal infections (Pfaller MA, 2004). Although the antifungal active principles are diverse and numerous, only a few classes of antifungal agents are currently available to treat yeast infections, due to the high toxicity of many of them (Spampinato \& Leonardi, 2013). High morbidity and mortality rates due to opportunistic yeast infections represent the ineffectiveness of the current antifungal therapies.

The present study revealed the effective in vivo anti-candidal activity of the extract of $P$. asparagi, and thus can be recommended as a potential source for development of a safe natural anti-candidal product for commercial utilization. Nevertheless, the information available of these compounds is still poor, but offer potential sources of novel natural products, for exploitation in medicine, agriculture and the pharmaceutical industry (Strobel \& Daisy, 2003). The potency of $P$. asparagi against this pathogen is attributed to the presence of effective antimicrobial agents in the endophytic fungal extract. However, the isolation of bioactive components and their characterization is underway for deeper insight into their functions.

\section{ACKNOWLEDGMENTS}

The authors acknowledge the financial support received from Department of Biotechnology, Govt. of India to carry out the present work and DST-PURSE programme for supplementary support. SAIF, NEHU, Shillong is also highly acknowledged for providing the facility of scanning electron microscopy.

\section{RESUMEN}

Efecto anticandida de hongos endofíticos aislados de Calotropis gigantea. Candida albicans es la causa más común de infecciones fúngicas en animales y aves. La comprensión de la creciente resistencia de C. albicans a varios agentes terapéuticos antifúngicos es importante para descubrir nuevas alternativas anti-candida. El presente estudio investigó el potencial anti-candida de cinco extractos de hongos endofíticos, aislados de la planta etnoveterinaria tropical, Calotropis gigantea. En primer lugar se evaluaron las actividades antifúngicas in vitro de los extractos de hongos endofíticos por el método de difusión de pozos. En segundo lugar, las células de C. albicans se trataron con un potente extracto para observar cambios ultrastructurales significativos. Para investigar más a fondo la actividad antifúngica in vivo del extracto, se realizaron algunos experimentos de laboratorio con ratones, y posteriormente, los diferentes órganos se estudiaron bajo microscopio electrónico para cualquier deformidad. Phomopsis asparagi mostró la mejor actividad anti-candida con una concentración inhibitoria mínima (MIC) de 46.9 $\mu \mathrm{g} / \mathrm{mL}$. El patógeno de prueba fúngico (C. albicans) presentó diversas deformidades celulares al ser tratado con el extracto de $P$. asparagi. Los estudios histopatológicos de los órganos vitales de los ratones tratados con el potente extracto fúngico no mostraron ninguna condición patológica significativa cuando se observaron con un microscopio electrónico de barrido. Por lo tanto, P. asparagi puede ser un candidato potencial para agentes anti-candida contra $C$. albicans. Los estudios futuros se centrarán en el aislamiento de los componentes bioactivos del extracto.

Palabras clave: hongos endofíticos, anti-Candida, Candida albicans, microscopio electrónico de barrido, ultraestructura.

\section{REFERENCES}

Bacon, C. W., \& White, J. F. (2000). Microbial endophytes. New York: M. Dekker.

Bridge, P. D., \& Arora, D. K. (1998). Interpretation of PCR methods for species definition. In P. D. Bridge, D. K. Arora, C. A. Reddy, \& R. P. Elander (Eds.), 
Applications of PCR in mycology (pp. 63-84). Wallingford: CAB International.

Deshmukh, S. K., Mishra, P. D., Kulkarni-Almeida, V. S. A., Sahoo, M. R., Periyasamy, G., \& Goswami, H. (2009). Anti-inflammatory and anticancer activity of ergoflavin isolated from an endophytic fungus. Chemistry and Biodiversity, 6, 784-789.

Dhankhar, S., Kumar, S., Dhankhar, S., \& Yadav, J. P. (2012). Antioxidant activity of fungal endophytes isolated from Salvadora oleoidesdecne. International Journal of Pharmaceutical Science,4, 0975-1491.

Du, F. Y., Li, X. M., Li, C. S., Shang, Z., \& Wang, B. G. (2012). Cristatumins A-D, new indole alkaloids from the marine-derived endophytic fungus Eurotium cristatum EN-220. Bioorganic and Medical Chemistry Letters, 22, 4650-4653.

Ecobichon, D. J. (1992). The basis of toxicity testing (3rd ed.). Boca Raton: CRC Press.

Faria, P. S. A., Senábio, J. A., Soares, M. A., Silva, F. G., Cunha, A. P. A., \& Souchie, E. L. (2016).Assessment of functional traits in the assemblage of endophytic fungi of Anacardium othonianum Rizzini. Pakistan Journal of Botany, 48, 1241-1252.

Gong, L. J., \& Guo, S. X. (2009). Endophytic fungi from Dracaena cambodiana and Aquilaria sinensis and their antimicrobial activity. African Journal of Biotechnology, 8, 731-736.

Govindappa, M., Sadananda, T. S., Channabasava, Ramachandra, Y. L., Chandrappa, C. P., Padmalatha, R. S., \& Prasad, S. K. (2015). In vitro and in vivo antidiabetic activity of lectin ( $\mathrm{N}$-acetyl-galactosamine, $64 \mathrm{kDa}$ ) isolated from endophytic fungi, Alternaria species from Viscum album on alloxan induced diabetic rats. Integrative Obesity and Diabetes, 1, 11-19.

Huang, G. J., Chen, H. J., Chang, Y. S., Sheu, M. J., \& Lin, Y. H. (2007). Recombinant sporamin and its synthesized peptides with antioxidant activities in vitro. Botanical Studies, 48, 133-140.

Khan, M. A. U., Ashfaq, M. K., Zuberi, H. S., Zuberi, H. S., Mahmood, M. S., \& Gilani, A. H. (2003). The in vivo antifungal activity of the aqueous extract from Nigella sativa seeds. Phytotherapy Research, 17, 183-186.

Konrath, E. L., Ortega, M. G., Bordignon, S. L., Apel, M. A., Henriques, A. T., \& Cabrera, J. L. (2012). Alkaloid profiling and anticholinesterase activity of South American Lycopodiaceae species. Journal of Enzyme Inhibition and Medicinal Chemistry, 28, 218-222.

Kuwamura, M., Ide, M., Yamate, J., Shiraishi, Y., \& Kotani, T. (2006). Systemic candidiasis in a dog, developing spondylitis. The Journal of Veterinary Medical Science, 68, 1117-1119.
Lyngwi, L. A., Koijam, K., Sharma, D., \& Joshi, S. R. (2013). Cultivable bacterial diversity along the altitudinal zonation and vegetation range of tropical Eastern Himalaya. Revista de Biología Tropical, 61, 467-490.

Myers, N., Mittermeier, R. A., Mittermeier, C. G., Fonseca, G. A. B., \& Kent, J. (2012). Biodiversity hotspot for conservation priorities. Nature, 403, 853-858.

Naglot, A., Goswami, S., Rahman, I., Shrimali, D. D., Yadav, K. K., Gupta, V. K., Rabha, A. J., Gogoi, H. K., \& Veer, V. (2015). Antagonistic potential of native Trichoderma viride strain against potent tea fungal pathogens in North East India. The Plant Pathology Journal, 31(3), 278-289.

Nascente, P. da S., Meinerz, A. R. M., de Faria, R. O., Schuch, L. F. D., Meireles, M. C. A., \& de Mello, J. R. B. (2009). CLSI broth microdilution method for testing susceptibility of Malassezia pachydermatis to thiabendazole. Brazilian Journal of Microbiology, $40,222-226$.

Nath, A., Chattopadhyay, A., \& Joshi, S. R. (2015). Biological activity of endophytic fungi of Rauwolfia serpentina Benth: An ethnomedicinal plant used in folk medicines in Northeast India. Proceedings of National Academy Sciences, India, Biological Sciences, 85, 233-240.

Nath, A., Raghunatha, P., \& Joshi, S. R. (2012). Diversity and biological activities of endophytic fungi of Emblica officinalis, an ethnomedicinal plant of India. Mycobiology, 40, 18-30.

Nath, A., \& Joshi, S. R. (2013). Bioactivity assessment of endophytic fungi associated with the ethnomedicinal plant Potentilla fulgens. World Journal of Pharmaceutical Research, 2, 2596-2607.

Nath, A., \& Joshi, S. R. (2016). Endophytic fungi from tropical ethnoveterinary plants and their antibacterial efficacy against Pasteurella multocida Capsular Type A strain. Revista de Biología Tropical, 64, 733-745.

Owais, M., Sharad, K. S., Shehbaz, A., \& Saleemuddin, M. (2005). Antibacterial efficacy of Withania somnifera (Ashwagandha) an indigenous medicinal plant against experimental murine salmonellosis. Phytomedicine, 12, 229-235.

Peláez, F., Cabello, A., Platas, G., Díez, M. T., González, del Val, A., Basilio, A., ..., \& Kurtz, M. B. (2000). The discovery of enfumafungin, a novel antifungal compound produced by an endophytic Hormonema species biological activity and taxonomy of the producing organisms. Systemic and Applied Microbiology, 23, 333-43.

Pannu, J., McCarthy, A., Martin, A., \& Sutcliffe, J. (2009). NB-002, a novel nanoemulsion with broad antifungal activity against dermatophytes, other filamentous 
fungi, and Candida albicans. Antimicrobial Agents and Chemotherapy, 53, 3273-3279.

Petrini, O. (1986). Taxonomy of endophytic fungi of aerial plant tissues. In N. J. Fokkenna, \& J. Van Den Heuvel (Eds.), Microbiologyof the Phylosphere (pp. 175187). Cambridge: Cambridge University Press.

Pretsch, A., Nagl, M., Schwendinger, K., Kreiseder, B., Wiederstein, M., Pretsch, D., Genov, M., ..., \& Wiesner, C. (2014) Antimicrobial and anti-inflammatory activities of endophytic fungi Talaromyces wortmannii extracts against acne-inducing bacteria. Plos One, 9, doi:10.1371/journal.pone.0097929

Sasidharan, S., Zuraini, Z., Latha, L. Y., \& Suryani, S. (2008). Fungicidal effect and oral acute toxicity of Psophocarpus tetragonolobus root extract. Pharmaceutical Biology, 46, 261-265.

Srivastava, S., Singh, A. P., \& Rawat, A. K. S. (2015). Comparative botanical and phytochemical evaluation of Calotropis procera Linn. and Calotropis gigantea Linn. Root. Journal of Applied Pharmaceutical Science, 5, 041-047.

Spampinato, C. \& Leonardi, D. (2013). Candida infections, causes, targets, and resistance mechanisms: traditional and alternative antifungal agents. BioMed Research International, 204-237.

Strobel, G., \& Daisy, B. (2003). Bioprospecting for microbial endophytes and their natural products. Microbiology and Molecular Biology Review, 67, 491-502.
Strobel, G., Daisy, B., Castillo, U., \& Harper, J. (2004). Natural products from endophytic microorganisms. Journal of Natural Products, 67, 257-268.

Tamura, K., Peterson, D., Peterson, N., Stecher, G., Nei, M., \& Kumar, S. (2011). MEGA5: molecular evolutionary genetics analysis using maximum likelihood, evolutionary distance, and maximum parsimony methods. Molecular Biology Evolution, 28, 2732-2739.

Tan, D., Fu, L., Han, B., Sun, X., Zheng, P., \& Zhang, J. (2015). Identification of an endophytic antifungal bacterial strain isolated from the rubber tree and its application in the biological control of Banana Fusarium Wilt. Plos One, 10, doi:10.1371/journal. pone. 0131974

Tanaka, M., Fukushima, T., Tsujiro, Y., \& Fujimori, T. (1997). Nigrosporins A and B, new phytotoxic and antibacterial metabolites produced by a fungus Nigrospora oryzae. Bioscience Biotechnology and Biochemistry, 61, 1848-1852.

Verma, V. C., Kharmar, R. N., \& Strobel, G. A. (2009). Chemical and functional diversity of natural products from plant associated endophytic fungi. Natural Product Communication, 4, 1511-1532.

Vijayarathna, S., Zakaria, Z., Chen, Y., Latha, L. Y., Kanwar, J. R., \& Sasidharan, S. (2012). The antimicrobial efficacy of Elaeis guineensis: characterization, in vitro and in vivo studies. Molecules, 17, 4860-4877. 